\title{
中性子ラジオグラフィ・放射化分析の農業関連研究への応用
}

\author{
中西 友子
}

(東京大学大学院農学生命科学研究科)

\section{Application of Neutron Radiography and Activation Analysis in Agriculture Field}

Tomoko M. Nakanishi

Graduate School of Agricultural and Life Sciences, The Univ. of Tokyo

\section{0}

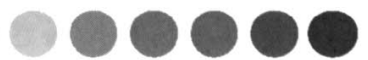

1.はじめに

農業における技術革新は大きく施肥法と育種法 に集約されてきた (下表)，効率良くまた環境に 配慮した施肥法開発は, 現在でも全国の試験場な ど, 現場に近い研究所において広く研究され続け ている重要課題である. 育種法では, 新しい品種 の開発から, 現場における生育法そのものの技術 までが開発されてきた。特に新品種開発では, 遺 伝子技術を駆使したストレス而性などの新しい性 質の付与, ならびに放射線を用いた突然変異体の 選抜など“種”の開発が行われてきた。

\begin{tabular}{|c|}
\hline 農業の技術開発 \\
1. 施肥法 : 施肥 (水供給も含む) の効率化 \\
肥料の物理·化学形態 \\
施肥法 (タイミング) \\
2. 育種法 : 新品種開発 (種の開発) \\
遺伝子組み換え, 放射線照射 \\
: 生育プロセスの開発 \\
• 環境との関連 : 負荷, 浄化技術 \\
・保存法の開発 : 種子, 作物保存技術 \\
\hline
\end{tabular}

種の開発では，近年，遺伝子組み換え作物につ いての社会的認知を得ることが困難となってきて からは, 米国を始めとして放射線による突然変異 育種が急激に見直されてきている.

一方学会面では, 土壤・肥料・植物栄養関連の 4 学会会員の内, その半数以上（約 1500 人）が植 物栄養学に従事している。植物栄養学は日本では かつての肥料学から発展してきたため実学が基本, つまり産学協同研究面が大であったが, 新品種開 発そのものについてはあまり活発ではなかった感 がある．穀物生産には国の規制があることならび に野菜などの作物生産は市場規模そのものがあま り大きくないため企業としての魅力が少なかった ためと考えられる。種子については種子そのもの の開発よりも種子の処理法・保存法などの方が企 業の開発研究における大きな課題であった。その 他, 企業面から考えると付加価值の高い植物, 特 に薬草や香料などの開発が見込まれるが，まだ実 際の植物体以上にこれらの植物成分を産生寸る

（企業生産に見合う）系は見つかっていない。
これらの農業関連のバックグラウンドを踏まえ て，どのような方面で放射線技術の応用が見込ま れ，または期待されるかについて，いくつかの例 を紹介したい。

\section{2. 中性子ラジオグラフィ(NRG)}

上に述べたように農業関連産業では，まず，何 といっても肥料関連の技術開発が重要である。施 肥法では, ゆっくりと必要量だけ植物に供給する という肥効調節型肥料開発が環境にも優しいこと からも肥料会社を中心に進められている。.土壌中 の肥料がどのように植物に供給されるかまた植物 の根はそれによってどのように生育するかは, 肥 効調節型肥料開発には久かせないデータである。

NRG では，通常見ることができない土壌中の生 きた根の生育過程が可視化されるため, 肥料開発 への応用が大いに期待される。つまり，どのよう に化学修飾した肥料をどのような位置に施肥すれ ば良いかの判断評価が可能となる。

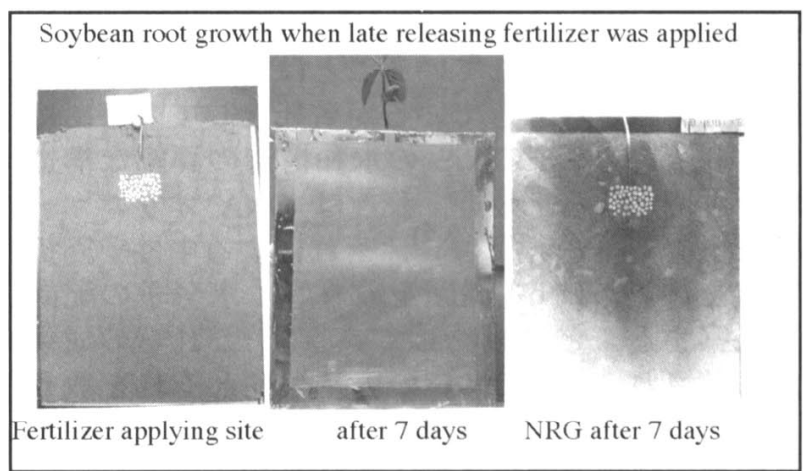

次にNRG 応用が見込まれる分野には種子処理. 保存の分野が挙げられる. 保存される種子に含ま れる水分管理は大きな課題である。プライミング 処理と呼ばれる種子への限られた量の水分や化学 薬品の添加は発芽時期のコントロール技術として 特に付加価値の高い種子で行われている. しかし, 品種によって種子への処理法が異なるため, 種子 中の水分分布の可視化は種苗会社にとっては大き な魅力だろう。我々は JRR-3M を用いた種子への 水分吸収の可視化を試みてみたものの, 分解能の 点からさらに改良が必要なことが示された。産学 連携課題をす寸女るためにはより高い分解能, つ 
NRG image of seeds during water absorbing process
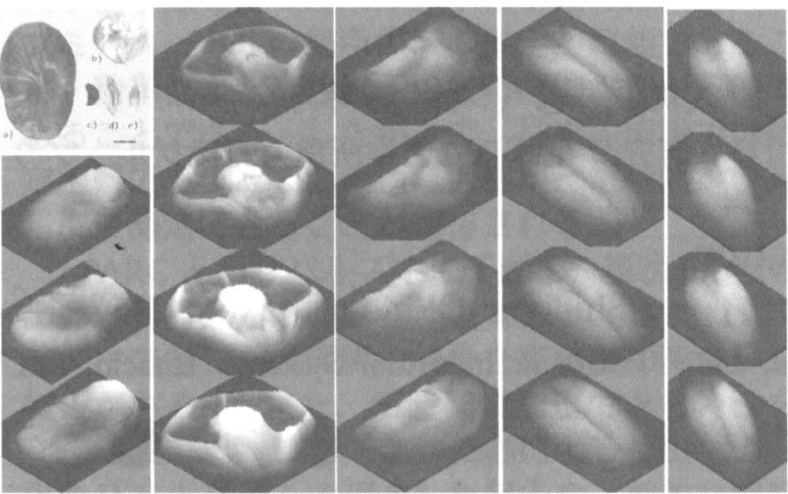

broad bean corn morning-glory wheat rice

Every 2 hours of water absorption, NRG was taken. The upper most images are the original ones in the left upper image (bar: $5 \mathrm{~mm}$ ).

このような水分動態に着目すると，食品におけ る水分吸収のイメージングも期待される課題では あるが，種子の場合と同様，実際の応用にあたっ ては現状よりももう少し高い分解能が望まれるだ ろう。その他，開花状態を長くするなど花茾にお ける水分保持能の可視化へも NRG の技術応用が 有用と見込まれるが，実際に応用されるかどうか は市場規模に大きく依存するだろう。

\section{3. 放射化分析(INAA)}

INAA は即発 $\gamma$ 線分析も含め, 元素量の絶対値 が求まる唯一の手法として非常に大切である。特 にこれからは環境試料を中心として, ますます超 微量测定技術の信頼性が求められてくる. 植物も 含め，環境試料中の元素量が微量であればあるほ ど，非破壊手法が重要となってくる，現在広く使 用されている ICP-AES を中心とした溶液法では 試料調製の際, 使用する試薬からの目的元素の「コ ンタミ」と何\%溶解して溶液になるかという「溶 液化効率」のふたつの問題をクリアすることはで きない, 従って, 非破壊手法でかつ微量が測定で きる INAA は非常に重要であり, 将来に渡って無 くてはならない技術である.

特に農業分野ではこれから重金属污染ならびに その作物への移行が大きな環境問題になる恐れが ある、WHO/FAO 合同委員会である CODEX 委員 会が，穀物・野菜を含め，重金属の規制濃度の大 幅な引き下げを推奨しはじめているからである. 我が国ではかつての公害訴訟の際に基準は決めら れたものの，本委員会の規制が取り入れられた場 合にはより厳しい対応が求められる。特に作物中 における可食部への重金属移行量を測定するため には, 通常の分析法よりも高い感度が要求される ことになる。そこで, 特に $\mathrm{Cd}$ や $\mathrm{Hg}$ などの重金 属の測定感度が非常に高いと予想される多重 $\gamma$ 線 分析の応用発展が大きく期待されるだろう.

通常測定できないレベルの元素分析例として INAA による $\mathrm{Al}$ 分析結果を示す. ダイズの根先 の $\mathrm{Al}$ 量は時間変化し, 特に明るくなる少し前に 高くなることが示された。このダイズは特に $\mathrm{Al}$ を添加したものではなく, 測定された $\mathrm{Al}$ は種子
中に含まれていた $\mathrm{Al}$ である。そのため, 幼植物 が生育するに従って次第に濃度が減少している。

$\mathrm{Al}$ concentration in root tip of soybean seedling

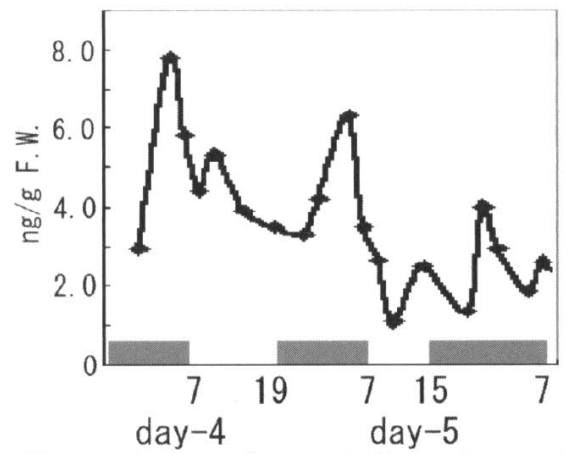

(Black columns at bottom indicate dark period)

このように INAA で今までの手法では測定でき なかった元素の測定が見込まれることは農学関係 に携わる者にとって期待される面だろう。

4.おおりに

NRG や INAA は日本ではいずれも原子力研究 所などの大型設備を必要とする。つまり，農業 やフィールドなどの現場で利用できないことから， 実際に実験室に試料を持ち込み，他の技術とそ の特徴や技術の高さを競争することになるだろう. つまり，通常の手法ではできない，放射線なら ではの技術開発の方向性が示される必要がある. そのひとつの面は非破壊手法での分解能の向上を 図ることだろう。

Abstract:

Application of neutron beam technique, neutron radiography and instrumental neutron activation analysis, in agriculture field is presented. In the case of neutron radiography (NRG), non-destructive analyzing method of root development has an advantage for the development of the late releasing fertilizer, because NRG visualizes the root imbedded in soil during its growth. When the resolution of the image is developed to be as high as to analyze water movement within a seed, NRG might be an important tool in seed or food treatment. Instrumental neutron activation analysis (INAA) has a great advantage, for it enables to measure the absolute amount of trace elements, non-destructively. With its high sensitivity to determine the heavy elements, INAA is expected for its wide application to analyze environmental samples. 